\title{
A Whole Vessel from the Henry Brown \#2 Site (41HS262), a Historic Nadaco Caddo Site in Harrison County, Texas
}

Timothy K. Perttula

Heritage Research Center, Stephen F. Austin State University

Bo Nelson

Heritage Research Center, Stephen F. Austin State University

Follow this and additional works at: https://scholarworks.sfasu.edu/ita

Part of the American Material Culture Commons, Archaeological Anthropology Commons, Environmental Studies Commons, Other American Studies Commons, Other Arts and Humanities Commons, Other History of Art, Architecture, and Archaeology Commons, and the United States History Commons

Tell us how this article helped you.

This Article is brought to you for free and open access by the Center for Regional Heritage Research at SFA ScholarWorks. It has been accepted for inclusion in Index of Texas Archaeology: Open Access Gray Literature from the Lone Star State by an authorized editor of SFA ScholarWorks. For more information, please contact cdsscholarworks@sfasu.edu. 


\section{A Whole Vessel from the Henry Brown \#2 Site (41HS262), a Historic Nadaco Caddo Site in Harrison County, Texas}

\section{Creative Commons License}

\section{(c) (1) (8)}

This work is licensed under a Creative Commons Attribution-NonCommercial 4.0 International License 


\title{
A Whole Vessel from the Henry Brown \#2 Site (41HS262), a Historic Nadaco Caddo Site in Harrison County, Texas
}

\author{
Timothy K. Perttula and Bo Nelson
}

\section{INTRODUCTION}

The Henry Brown \#2 site is a poorly known Historic Caddo site (dating after ca. A.D. 1685) affiliated with the Nadaco Caddo on Potters Creek in Harrison County, Texas (see Fields and Gadus 2012:642 and Figure 9.5). It is a cemetery site located about 0.5 miles from the J. O. and Henry Brown (or Brown \#1) site (41HS261), another Historic Caddo cemetery (Jones 1968:127). A single fragmentary ceramic vessel from the Henry Brown \#2 site has been identified in the collections of the Gregg County Historical Museum in Longview, Texas, and we recently documented this vessel in July 2013.

\section{VESSEL}

SITE NAME OR SITE NUMBER: Henry Brown \#2

VESSEL NO.: 2003.08.1587

NON-PLASTICS AND PASTE: grog and bone

VESSEL FORM: Carinated bowl

RIM AND LIP FORM: Direct rim and rounded, exterior folded lip

CORE COLOR: B (fired and cooled in a reducing environment)

INTERIOR SURFACE COLOR: dark grayish-brown

EXTERIOR SURFACE COLOR: dark grayish-brown; fire clouds on the rim and body

WALL THICKNESS (RIM, BODY, AND BASE IN MM): rim, 6.7 mm; body, 6.4 mm

INTERIOR SURFACE TREATMENT: burnished

EXTERIOR SURFACE TREATMENT: burnished

HEIGHT (IN CM): N/A

ORIFICE DIAMETER (IN CM): 20.0

DIAMETER AT BOTTOM OF RIM OR NECK (IN CM): 20.1

BASE DIAMETER (IN CM) AND SHAPE OF BASE: N/A

ESTIMATED VOLUME (IN LITERS): N/A 
DECORATION (INCLUDING MOTIF AND ELEMENTS WHEN APPARENT): The rim panel has an engraved motif that may be repeated four times around the vessel. The motif consists of one set of two vertical arcing lines between a large rectangular bracket and a corresponding set of opposed vertical arcing engraved lines that originate under the vessel lip and from the vessel carination (Figure 1).

PIGMENT USE AND LOCATION ON VESSEL: none

TYPE AND VARIETY [IF KNOWN]: Unidentified fine ware

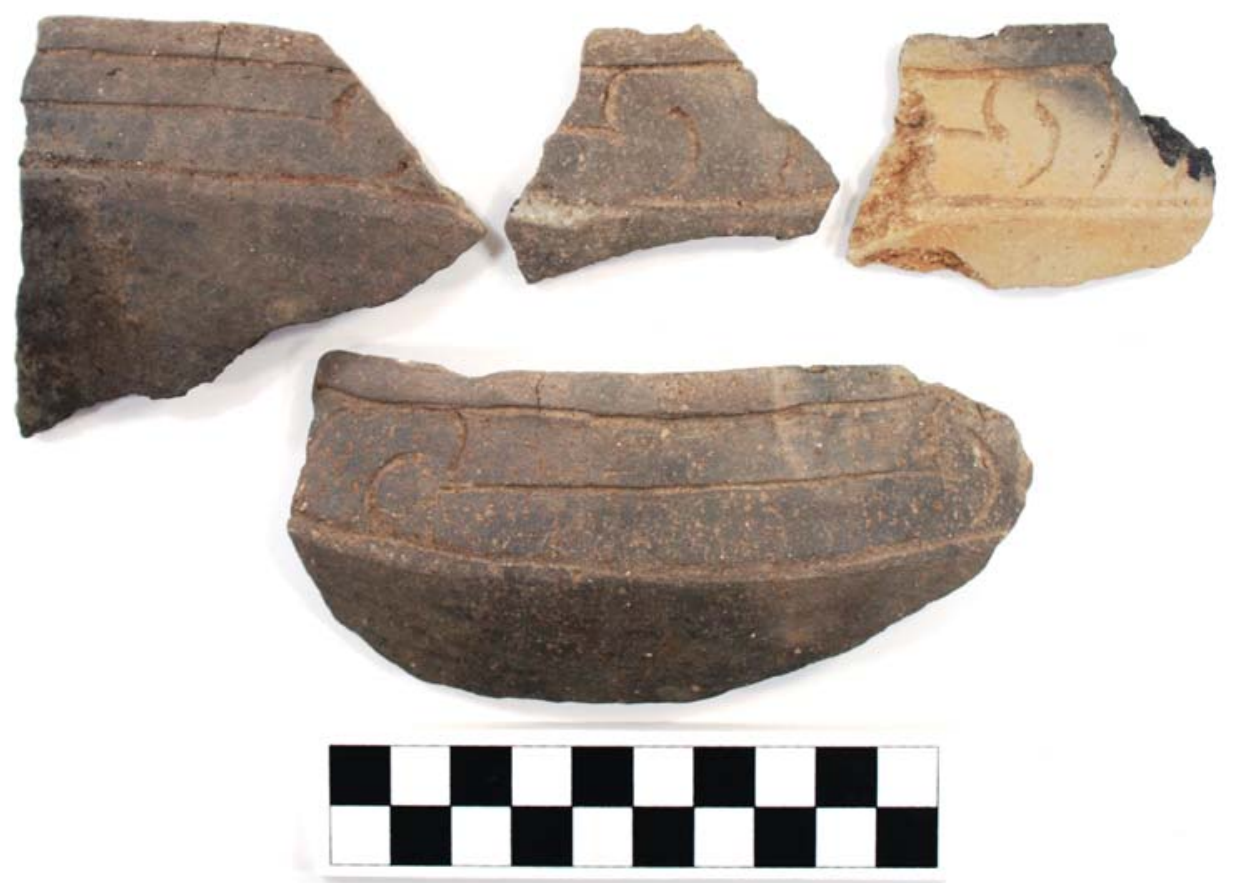

Figure 1. Unidentified engraved carinated bowl from the Henry Brown \#2 site.

\section{CONCLUSIONS}

It is known that the Henry Brown \#2 site has burials with both European trade goods and Caddo ceramic vessels, although little specific information is available about the contents of the burials or their specific cultural associations other than that it appears to be a component of the Kinsloe phase. This is a historic Caddo phase with a number of sites in the middle Sabine River basin that are thought to be affiliated with the Nadaco Caddo. The one vessel from the site known to be in the Gregg County Historical Museum is an engraved carinated bowl of unidentified type.

\section{ACKNOWLEDGMENTS}

We thank Patti Haskins of the Gregg County Historical Museum for facilitating the vessel documentation process. 


\section{REFERENCES CITED}

Fields, R. C. and E. F. Gadus (editors)

2012 Archeology of the Nadaco Caddo: The View from the Pine Tree Mound Site (41HS15), Harrison County, Texas. 2 Vols. Reports of Investigations No. 164. Prewitt \& Associates, Inc., Austin.

Jones, B. C.

1968 The Kinsloe Focus: A Study of Seven Historic Caddoan Sites in Northeast Texas. Master's thesis, Department of Anthropology, University of Oklahoma, Norman. 